\author{
Andrè Horgen \\ Institutt for idrett- og friluftsliv, Høgskolen i Telemark
}

\title{
Educational expeditions - et norsk perspektiv
}

\begin{abstract}
The topic of this article is the Norwegian concept of "friluftsliv" (outdoor life), used as a pedagogical tool to support personal growth. While supporting personal growth appears to be a central pedagogical strategy within AngloAmerican and British youth expeditions and adventure programming, this does not appear to be case in the Norwegian outdoor tradition. My research question is: Do Norwegian Outdoor Education students experience a learning outcome related to personal growth, and to their abilities as leaders/mentors, during ski expeditions? I have collected data through a three-year period, after three ski expeditions with Outdoor Education students from an outdoor bachelorprogramme at Telemark University College.

The students have given written answers to questions regarding personal growth in which several informants' express thoughts about experiences related to "self" and "identity". They reflect upon experiences related to "mastering" and "performing", to acceptance of their own strengths and weaknesses, and about developing self-confidence. They also reflect upon learning outcomes related to interpersonal relations and abilities, self-control, communication and caregiving. The informants have experienced, as leaders/mentors, that it is important to be able to, to "read" situations, to make good assessments of the situations, and to make good decisions related to the situations. As a follow up to this, the informants highlight the importance of being aware of each individual in the group, the importance of encouragement, being positive and caregiving. This study has shown that ski expeditions in "a Norwegian tradition" may have a potential when it comes to encouraging reflections related to personal growth and leadership abilities. Hopefully this study can contribute to increased awareness of the pedagogical potential, for personal growth, within the Norwegian concept of "friluftsliv"pedagogy?
\end{abstract}

Key words: Educational expeditions, Adventure programming, Outdoor education and Personal growth

\section{Sammendrag}

Artikkelen handler om friluftsliv brukt pedagogisk med tanke på personlig utvikling. Bakgrunnen er en undring rundt hvorfor temaet personlig utvikling, som står så sentralt $i$ britisk og angloamerikansk pedagogisk friluftslivs- 
tradisjon, ikke er viet større plass i norsk friluftslivspedagogisk tradisjon. Problemstillingen har vcert: Opplever norske bachelorstudenter i friluftsliv at de lerer noe om seg selv og sine egenskaper som ledere under lange ferder $i$ vinterfjellet? Datainnsamlingen har foregått over tre år, i etterkant av tre lange vinterferder med tjuefem 3. års studenter ved Høgskolen i Telemark. Studentene har svart skriftlig på spørsmål knyttet til personlig utvikling. Flere av dem gir uttrykk for en opplevelse $a v \stackrel{\text { a }}{\text { ha }}$ gjort seg erfaringer knyttet til selvbilde/identitet som kan koples til personlige utvikling. Informantene reflekterer bl.a. over opplevelser knyttet til det å mestre og prestere, det å akseptere egne styrker og svakheter, samt det å utvikle troen på seg selv, også $i$ lederrollen. I tillegg reflekteres det over opplevelser av laring knyttet til mellommenneskelig ferdigheter, selvkontroll og kommunikasjon, samt mellommenneskelig forhold knyttet til utøvelsen av lederskap og over omsorgsoppgaver lederskapet innebcrer. Opplevelser av læering knyttet til det å ha overblikk, lese situasjoner, gjøre vurderinger og treffe nødvendig tiltak, er også gjenstand for refleksjon. I forlengelsen av dette reflekteres det over viktigheten av å ha fornemme den enkelte, det å oppmuntre, vcere positiv og gi omsorg. Studien har vist at lange vinterferder, i en norsk tradisjon, har et potensiale til å utløse refleksjoner knyttet til personlig utvikling og ledelse. Kanskje kan denne studien øke bevisstheten rundt de pedagogiske mulighetene som ligger i menneskers møter med andre mennesker i natur?

Nøkkelord: Friluftsliv

\section{Innledning}

Temaet personlig utvikling står sterkt i britisk og angloamerikansk Outdoor Education tradisjon. (Dimock \& Henday, 1929; Dewey, 1938; Priest \& Gass, 1997; Raffan, 2002; Stonehouse, 2010; Loynes, 2010; Asfeldt, Hvenegaard, \& Urberg, 2010, D’Amato \& Krasny, 2011). Dette i kontrast til den pedagogiske tradisjonen innenfor høyere utdanning i friluftsliv i Norge, hvor man i større grad har sett på friluftslivsutdanning som en profesjonsutdanning rette mot formidling (Faarlund, 1974; Tordsson, 2014). Denne artikkelen handler om friluftsliv brukt pedagogisk med tanke på personlig utvikling. Artikkelen ser til britisk og angloamerikansk tradisjon, og stiller spørsmål vedrørende temaet personlig utvikling i norsk friluftslivspedagogisk tradisjon. Målet med studien har vært å undersøke om norske bachelorstudenter i friluftsliv opplever at de lærer/erfarer noe om sin egen person og sine leder/veileder-egenskaper under lange ferder i vinterfjellet. Basert på spørreundersøkelser blant norske friluftslivstudenter, som har deltatt på slike ferder, konkluderes det med at vinterferder i norsk friluftslivspedagogisk tradisjon har et pedagogisk potensiale både mht. personlig utvikling og utvikling av lederegenskaper. 


\section{Bakgrunn}

Robert B. Powells initiativ til dannelsen av The Boy Scouts (1907) i Storbritannia, og Ernest Thompson Setons The League of Woodcraft Indians (1902) i USA, eksemplifiserer hvordan personlig utvikling i møtet med naturen ble satt i inn i en pedagogisk kontekst tidlig på 1900-tallet (The Woodcraft folk, 2012). "It'll develop your character" og "Making men out of boys" er fraser som ofte brukes når man skal legitimere ekspedisjoner blant ungdom i britisk og angloamerikansk tradisjon (Stonehouse, 2010, s. 17; Hattie, Marsh, Neill, \& Richards, 1997, s. 44; Dimock \& Henday, 1929). Siden Victoria-tiden har kvaliteter som bl.a. hardnakkethet, stå på vilje, utholdenhet, tålmodighet og selvdisiplin falt inn under samlebegrepet karakter. Tanken er at "adventure" og "expeditions" kan bidra til å justere menneskers indre, moralske kompass og dermed bygge karakter (Raffan, 2002, s. 2). I følge Chris Loynes (2010) sprang ideen om "youth expeditions" med tanke på karakterbygging, ut fra en bekymring for det moralske forfallet blant ungdommen (Loynes, 2010, s. 7). Tradisjonen med "youth expeditions for educational purposes" ble videreført i mange land, først og fremst av Kurt Hahns Outward Bound (fra 1941) (Raffan, 2002, s. 8; Outward Bound, 2012). "Expeditions were becoming a vehicle for personal fulfillment, and youth expeditions began to justify their endeavors in terms of the value of adventure for personal development” (Loynes, 2010, s. 9). Her er det viktig å understreke at det ikke er snakk om terapeutisk behandling i form av ekspedisjoner rettet mot grupper med særlige vansker eller behov. Vi snakker om ungdomsekspedisjoner for normalt fungerende tenåringer og unge voksne i begynnelsen av 20-årene. Når Kut Hahn selv skulle beskrive Outward Bound bevegelsen skrev han eksempelvis følgende:

[OB] was not started to teach people how to live in the mountains but to use the mountains as a classroom to produce better people, to build caracter, to instill intensity of individual and collective aspiration on which an entire society depends for its survival (Asfeldt, Hvenegaard, \& Urberg, 2010, s. 70).

Denne tradisjonen, med bl.a. reformpedagogen John Dewey som ledestjerne (Dewey, 1938), har også funnet vei inn i såkalte "university expeditions” der "personal growth", "leadership development" og "spiritual exploration" trekkes frem som sentrale elementer (Asfeldt, Hvenegaard, \& Urberg, 2010, s. 68; Asfeldt, Potter, \& Henderson, 2013). Afeldt m.fl. viser til Simon Beams (2004) som identifiserer visse kjennetegn på den klassiske ungdomsekspedisjon etter britisk mønster: Ekspedisjonen foregår eksempelvis til fots, på ski, med kajakk eller kano, i mer eller mindre naturlige omgivelser. Den består av en relativt isolert gruppe, gjerne heterogen i sin sammensetning, som er på en relativt fysisk krevende tur, der man lever et nokså enkelt liv i naturen mht. overnatting, matlaging, hygiene etc. (Asfeldt, Hvenegaard, \& Urberg, 2010, s. 69; National 
Outdoor Leadership School, 2012). Dette er kjennetegn vi også finner igjen innenfor "university expeditions" i USA og Canada, så vel som ved turene/ferdene i regi av friluftslivstudier på universitet/høgskole-nivå i Norge.

Sammenlikner vi tradisjonene innenfor friluftslivsstudier i Norge med Outdoor Education i landene nevnt ovenfor finner vi altså mange likhetstrekk når det gjelder form og innhold. Det som kanskje først og fremst skiller disse tradisjonene fra hverandre er betoningen av pedagogiske målsettinger om personlig vekst og utvikling, sammen med utvikling av lederegenskaper, som skal foregå underveis på ekspedisjonen. I norsk tradisjon ser man i større grad på friluftslivsutdanning som en profesjonsutdanning hvor de pedagogiske målsettingene ligger $\mathrm{i}$ det praktiske håndverket og veilederkompetansen studentene trenger for selv å kunne formidle ulike aspekter ved friluftslivet til ulike grupper. Nå skal det sies at tanker om at friluftslivet kan bidra til personlig vekst og utvikling, historisk sett, ikke er en fremmed tanke i Norge. Allerede i 1873 uttalte en av friluftslivets pionere i Norge, Emanuel Mohn, følgende: Jeg ser "[...] i disse fjellture en folkeoppdragende magt av stor betydning”. "[...] den styrke, det mod, den selvtillid, man erhverver sig der, fölger med ned i dalene og fæster sig i karakteren og hjælper os til at stå fast i og holde du i mange forhold i livet [...]" (Mohn, 1873, s. 18). Senere, i 1921, lanserte Fridtjof Nansen tanken om at friluftslivet skulle bidra til å utvikle høyverdige karaktertrekk: "[...] Se, i ødemarkene, i skogensomheten, med syn av de store vidder og fjernt fra den forvirrende larm, er det personligheter formes" (Winsnes, 1942, s. 579).

Lite tyder imidlertid på at Mohn og Nansens tanker fikk særlig gjennomslag innenfor skole- og organisasjonsvesenet som beskjeftiget seg med pedagogiseringen av friluftslivet her til lands. I Norge finnes det heller ikke forskning på området. Når friluftslivet etter hvert kom inn som en del av høyere utdanning i Norge på 1960/70-tallet, og i læreplanen for grunnskolen i 1974, var det med utgangspunkt i en allerede etablert friluftslivskultur som så på turen og turopplevelsene som høyverdige kvaliteter i seg selv. I denne konteksten ble utdanningsturene først og fremst legitimert gjennom viktigheten av å lære barn og ungdom nødvendige ferdigheter, noe som ikke minst var blitt aktualisert etter ulykkespåsken i 1967 som krevde 16 omkomne. Innenfor høyere utdanning ble friluftslivet i tillegg legitimert ved ideen om at friluftslivet skulle vekke folks bevissthet i miljøspørsmål. Fagområdet var lenge knyttet til en kritikk av industrisamfunnet med en visjon om at erfaringer med enkelt friluftsliv og naturnære livsformer skulle utvikle studentenes kunnskaper, ferdigheter og holdninger som kunne danne grunnlag for å realisere alternative, lite ressurskrevende, mer naturnære og naturvennlige livsformer (Faarlund, 1974; Tordsson, 2010). Senere er det institusjonaliserte og pedagogiserte friluftslivet i Norge i stor grad legitimert ved dets antatte positive effekt på menneskers fysiske og psykiske helse. 


\section{Teori}

Til grunn for pedagogikken innenfor tradisjonen med "youth expeditions" finner vi Dewey's reformpedagogikk fra 1930-årene. I Deweys pedagogikk står "learning by doing” sentralt, gjerne problemløsende, i samarbeid med andre. Flere aspekter ved Deweys pedagogikk fremheves som særlig aktuelle for "youth expeditions" og "adventure programming". F.eks. involvering av individet, erfaringslæring og opplevelse av umiddelbar relevans, vektlegges som sentrale elementer (Priest \& Gass, 1997, s. 14). "Experiential learning” trekkes frem som et ideal fordi: "[...] experiential theories of learning tend to be holistic in nature, incorporating cognition and behavior with conscious perceptions and reflections on experience” (Priest \& Gass, 1997, s. 15).

Ideene om "youth expeditions", og deres effekter på "personal growth", "leadership development” og "spiritual exploration", kan sies å være teoretisk forankret i "transformative learning theory", utviklet av Jack Mezirow, fra 1978. Transformativ læringsteori integrerer aktivitet/handling/praksis og selvrefleksjon, og er bl.a. inspirert av Deweys tanker om kritisk refleksjon som bindeledd mellom handling og læring, av Habermas teori om instrumentell kommunikativ læring, samt Frieres "frigjørende pedagogikk” (D’Amato \& Krasny, 2011, s. 239). I følge Mezirow er: "Transformative learning often precipitated by a "disorienting dilemma", which is followed by critical selfreflection, social interactions, planning for action, and building competence and self-confidence in new roles and relationships as a result of taking action" (Mezirow, 2000, her etter D’Amato \& Krasny, 2011, s. 239). Transformativ læring kan sies å foregå i kjølvannet av handling der deltakerne har gjort seg erfaringer som vanskelig fullt ut kan tolkes innenfor deres etablerte forutsetninger. Dette setter i gang kognitive og "reorganiserende" prosesser, som i sin tur leder til oppdagelsen av nye konstruksjoner som gjør de forvirrende elementene mer forståelig. I fortsettelsen forsøker deltakerne å tilpasse seg og endrer atferd (transformere), og dermed har læring skjedd. Det er denne læringen man tenker kan resultere i personlig utvikling, eller vekst om man vil (D’Amato \& Krasny, 2011, s. 239).

\section{Problemområde}

På denne bakgrunn kan det reises en rekke interessante spørsmål. Har virkelig "educational expeditions" den ønskede effekten på personlig vekst og utvikling, karakterdannelse, samt utviklingen av lederegenskaper? Tilsynelatende finnes omfattende dokumentasjon på effekter og goder ved "educational expeditions". En metastudie gjennomført av Hattie m.fl. i 1997 uttrykker imidlertid skepsis til mye av forskningen på området, og konkluderer med at bare noen av 
programmene har målbar effekt. Og innenfor de programmene som har målbar effekt kan effekten bare måles på visse deltakere, som har vært ute med visse instruktører (s. 72). Som en generell kritikk av forskningen på området viser denne metastudien til at det har vært en tendens til å vektlegge positive funn som viser ønsket effekt, samtidig som man har ignorert funn som tyder på det motsatte. I følge forskerne som står bak undersøkelsen har denne tendensen vært: "[...] disturbingly common” (s. 49). Mye av den internasjonale forskning er dessuten preget av en kvantitativ tilnærming og en overdreven tiltro til kvalitative data formidlet gjennom tall og tabeller.

Ut fra et norsk perspektiv kan man, i forlengelsen av dette, undres over om "educational expeditions” har annen, større, eller bedre effekt på personlig utvikling, karakterdannelse, samt utviklingen av lederegenskaper, enn tilsvarende turer/ferder i norsk tradisjon? Som vist ovenfor møter norske friluftslivsstudenter mange av de samme utfordringene som "Outdoor Ed. students". Kan det tenkes at personlig utvikling, karakterdannelse, samt utviklingen av lederegenskaper, også kan være en effekt innenfor høyere friluftslivsutdanning i norsk tradisjon? Dette til tross for at turene/ferdene ikke legges opp målrettet med tanke på dette? Svaret er trolig ja, men på ny kan man spørre om dette lar seg undersøke på en metodisk forsvarlig måte? Dette ligger utenfor denne studiens anliggende.

Her sees det som interessant og metodisk forsvarlig å undersøke hvordan ulike studentgrupper uttrykker sin opplevelse knyttet til personlig utvikling og utvikling av lederegenskaper. På denne bakgrunn kan følgende problemstillinger formuleres:

Opplever norske bachelorstudenter i friluftsliv at de lcerer/erfarer noe om seg selv under lange, krevende ferder i vinterfjellet?

Opplever de samme studentene at de lerer/erfarer noe om sine egenskaper som leder/veileder under disse ferdene?

\section{Metode}

Forskningsdesignet som er valgt tar utgangspunkt i spørreskjema med åpne svarkategorier (Holme \& Solvang, 1993). Undersøkelsesenhetene har svart skriftlig på en rekke åpne spørsmål. Datainnsamlingen har foregått over tre år, i etterkant av tre relativt lange vinterferder med 3. års studenter ved bachelorstudiet Friluftsliv, kultur- og naturveiledning, ved Høgskolen i Telemark. 


\section{Informantene}

Til sammen har 25 studenter, 8 kvinner og 17 menn, deltatt i prosjektet. Informantene er fordelt på tre ferder á 12-15 dagers varighet, henholdsvis i Sarek/Kebnekaise (2010), Jotunheimen (2011) og Svalbard (2012). Ferdene har vært gjennomført med ski og pulk, stort sett uten muligheter for etterforsyning fra hytter, eller på andre måter. Hver deltaker har trukket sin egen pulk med en startvekt på ca. 50-60 kg. Ferdene har medført daglige forflytninger á ca. 15-25 $\mathrm{km}$. Overnattingene har i all hovedsak foregått i telt. Hver deltaker har hatt leder/veileder oppgaver både i planleggingsfasen og under selve gjennomføringen av ferden.

Informantene har, etter gjennomført ferd, bl.a. fått i oppgave å reflektere over sin rolle i gruppen. I den forbindelse har de svart skriftlig på følgende spørsmål: Hvilken rolle eller roller fyller du i gruppen? Er din rolle utfyllende i forhold til de øvrige medlemmene, eller fører din rolle til friksjon eller konflikt på noe vis? Hva har du lært om deg selv på ferden? Videre har informantene fått i oppgave å reflektere rundt seg selv som leder/veileder for gruppen underveis på ferden. Hva har du lært om dine egenskaper som leder/veileder under ferden? Spørsmålene er utviklet på bakgrunn av en før-forståelse forankret i litteraturstudier. Generelle og åpne spørsmål er valgt for at synspunktene som kommer til uttrykk skal være et resultat av informantenes egen forståelse. En fordel med denne måten å hente inn data på er at forskeren i liten grad har styring med tankegangen til informantene (Holme \& Solvang, 1993).

\section{Metodekritikk}

Av de 25 informantene var det flere som hadde vanskeligheter med å reflektere over læringsutbyttet utover det rent praktiske. Noen behandlet dessuten noen av spørsmålene svært overflatisk, og enkelte avviste nærmest spørsmålstillingen, som irrelevant eller umulig å svare på. Om disse ikke hadde lært noe, eller bare manglet øvelse i og/eller evnen til å uttrykke det, blir spekulasjoner. Samlet sett medførte dette at antallet informanter som har gitt relevante svar er redusert fra 25 til vel halvparten. Deres tanker om læringsutbytte og erfaringer utgjør datagrunnlaget for denne undersøkelsen. Om evnen til å gi relevante svar ble svekket pga. frykten for å bli evaluert kan tenkes. Dette ble forsøkt omgått ved at karakteren som ble gitt var bestått/ikke bestått. Samtidig må det legges til at denne delen av oppgavesettet var en liten del av totalvurderingen. Trolig skyldes enkelte av informantenes manglende evne til å reflektere over disse spørsmålene, manglende øvelse $\mathrm{i}$ å foreta denne typen refleksjoner. Dette forholdet kan også skyldes at ferdene ikke hadde noen "effekt" på disse deltakerne. Dette korrespondere i så fall med funn gjort i undersøkelser av Outward Bound programmer og andre "Adventure programs”. Hatti m.fl. (1997) konkluderte eksempelvis med at noen av programmene de hadde undersøkt bare hadde målbar effekt på visse deltakere, som har vært ute med visse instruktører (s. 72). 
En av forskerens store utfordringer med tanke på prosjektets reliabilitet, har vært forskerens nærhet til informantene. Siden forskeren også var veileder på de tre ferdene var graden av nærhet stor. Fordelen ved dette har vært inngående kjennskap til hendelser og episoder som det refereres til i tekstene. Samtidig kan nærheten være et problem dersom informantene får et ønske om å skrive slik hun går ut i fra at forskeren venter. Dette problemet er forsøkt omgått ved at informantene ikke visste at svarene deres skulle brukes i et forskningsprosjekt. Oppgavene ble gitt som en del av en studentoppgave, og tillatelse til å bruke svarene i et forskningsprosjekt ble hentet inn i etterkant. En annen utfordring har vært for forskeren å unngå å lete etter trekk som bekrefter dennes før-dommer. Det kan også være vanskelig og fullt ut forstå motivene for og rekkevidden av det informantene gir uttrykk for. For å imøtegå disse utfordringene er det vektlagt å ta med direkte sitat som viser informantenes måte å uttrykke seg på. Dette vil bidra til å sikre prosjektets etterprøvbarhet. I den videre fremstillingen er det bevisst brukt sitater fra intervjuene, som et viktig hjelpemiddel for å nå leserne med resultatene av arbeidet (Holme \& Solvang, 1993).

Det er viktig å poengtere at studien er avgrenset til å omfatte hvordan studentene uttrykker sin opplevelse av personlig utvikling. Om de faktisk utvikler seg, og i hvilken grad de utvikler seg, omfattes ikke av undersøkelsen. Dette med begrunnelse $\mathrm{i}$ en metodologisk skepsis til såkalt inderlighetsfenomenologi der forskeren skal avdekke hva som "egentlig" foregår i og mellom mennesker. I følge Veiden, i innledningen til Berger og Luckmanns Den samfunnsskapte virkelighet er det ikke: "[...] sikkert man kommer nærmere den sosiale realitet gjennom såkalte "dybdeintervjuer" og "veldig nær" samtaler" (Veiden, 2000, s. 10).

\section{Resultater}

Når resultatene av undersøkelsen her skal presenteres ansees det som hensiktsmessig å starte med hva informantene mener de har lært om seg selv. Tre viktige stikkord i denne sammenheng er mestring, prestasjon og selvsikkerhet. Videre presenteres informantenes refleksjoner knyttet til kommunikasjon og roller, så refleksjoner rundt seg selv i leder- og veilederrollen, og til slutt refleksjoner knyttet til mellommenneskelig relasjoner. Resultatene kan leses som et uttrykk for hva skiekspedisjonene som "handling" har utløst av erfaringer, som i sin tur har satt igang kognitive prosesser der deltakerne har oppdaget sider ved seg selv, som igjen har ført til refleksjon rundt tilpassning og endring. I denne prosessen har det trolig foregått læring og personlig utvikling i tråd med Mezirows transformative læringsteori. 


\section{Mestring, prestasjon og selvsikkerhet}

Her belyses hvordan informantene uttrykker sin opplevelse av personlig utvikling, i hovedsak knyttet til mestring, prestasjon og selvsikkerhet. Flere gir uttrykk for å ha lært noe om seg selv, bl.a. det å akseptere egne styrker og svakheter, samt det å utvikle troen på seg selv.

Mange informanter slår innledningsvis fast noe i retning av at: "Turen har definitivt lært meg mye om meg selv”. Noen har opplevde stor grad av mestring og en følelse av å ha klart en seriøs utfordring. De fleste fremhever også ting de har lært som er direkte relevant for det å være ute på langtur, vinterstid, det å takle de spesifikke, praktiske oppgavene, utfordringene som oppstår underveis og den fysiske og psykiske påkjenningen. Noen har også oppdaget nye sider ved seg selv:

Jeg har en liten mistanke om at jeg vokser når andre krymper, på den måten at når XX hadde det vondt og YY har bakglatte ski og derfor manglet overskudd til å gå foran, så fikk jeg en eller annen automatisk reaksjon a la "jeg vil være sterk” og jeg fikk uventet energi til fortsatt å gå på. Det må ikke forstås som at jeg liker at andre har problemer, men som at jeg fikk energi til å gjøre en ekstra innsats.

En annen informant reflekterer over en indre kamp knyttet til mestring, prestasjon og det å prestere i en gruppe:

Det som har været det vanskeligste for meg på denne turen, har vært å akseptere at jeg ikke kunne prestere så mye som jeg ville ønske jeg kunne. [...] Dette har vært veldig vanskelig å akseptere, og er nok den viktigste årsaken til mitt til tider dårlige humør. Jeg går ofte med en indre kamp hvor jeg føler at jeg ikke yter nok for gruppen. [...]. Det er dette jeg må jobbe mest med, å ha en positiv tankegang, og bidra til et positivt miljø i gruppen.

Mot slutten av sitatet reflekterer informanten over, og gir seg selv mentale arbeidsoppgaver som vedkommende ønsker å jobbe videre med. Trolig et eksempel på en person som har gjort seg erfaringer og refleksjoner som har satt igang en prosess som kan lede til personlig vekst og utvikling. I forlengelsen av dette eksemplifiserer også en annen informant hvordan anstrengelsene og utfordringene kan lede til refleksjon rundt dette med selvutvikling, her knyttet til det å akseptere egne styrker og svakheter:

Som jeg har vært inne på tidligere, kan jeg bli enda bedre til å akseptere mine egne styrker og svakheter, dette vil sikkert gjøre at jeg kan være enda mer positiv. [...] Hvis det er noe jeg kunne gjort annerledes i forhold til gruppen og stemningen i gruppen, er det nok det å være klar over, og akseptere hva jeg kan og ikke kan og forholde meg til det.

Her er det viktig å understreke at de anstrengelsene deltakerne på disse ferdene har stått ovenfor er anstrengelser som naturlig har oppstått underveis, som de i 
stor grad har hatt innvirkning på gjennom aktiv deltakelse i planleggingsfasen og gjennom stor grad av medbestemmelse gjennom rådene underveis. Tilbake til informanten som utkjempet en indre kamp kan det observeres refleksjoner knyttet til vedkommendes opplevelse av eget lederskap. I følgende sitat reflekterer informanten over det å ha troen på seg selv i lederrollen:

Jeg har lært mye på denne turen. I forhold til mitt «lederskap» har jeg lært at jeg må tro mere på meg selv. De dagene jeg var dagsansvarlig, følte jeg at jeg fylte rollen fint, men samtidig brukte jeg en del krefter på min «indre kamp». Jeg følte da jeg måtte gå fremst, i hvert fall når der var fokus på å finne leirplass, noe som ikke alltid var så lett.

Refleksjoner rundt det å ha troen på seg selv, nærmere bestemt det å utvikle evnen til å tro på seg selv, ser ut til å være et særlig aktuelt tema blant flere av de kvinnelige informantene. Også denne tematikken ser ut til å utløses av opplevelser av mestring og prestasjon i relativt anstrengende situasjoner. Et annet eksempel på dette er sitatet under, der det fremgår at informanten har opplevd mestring underveis, samtidig som hun reflekterer over viktigheten av å lære seg å tro på seg selv, for i fremtiden å kunne gå inn i en veilederrolle:

Jeg føler jeg mestrer vinter bedre og bedre [...], og hvis jeg lærer å tro mer på meg selv, så vet jeg et eller annet sted at jeg ville mestre å ta på meg veilederoppdrag. Men jeg er enda så fersk i gamet at jeg er urutinert i forhold til det å se fremover i den grad som jeg opplever at andre på gruppen kan. Det vil jeg arbeide med, reflektere over og ikke være redd for å si det høyt og være ærlig - ovenfor gruppen og meg selv.

En tredje kvinnelig informant sier imidlertid eksplisitt at hun har opplevde å være en overskuddsperson, samtidig som hun gir uttrykk for et ønske om å fremstå som mer selvsikker i sitt lederskap. Etter en lang beskrivelse av en hendelse som ikke kan gjengis her, av hensyn til anonymisering, skriver vedkommende følgende:

Det at jeg opplevde å være en overskuddsperson, gav meg mye innsikt i mine veilederevner. Hvis man tar utgangspunkt i de beslutninger man tar i slike situasjoner og lærer å stole på seg selv, er det mye her man kan bruke. Jeg har definitivt lært mye som jeg vil trekke fram neste gang jeg står i en veilederrolle. Jeg har erfart at når jeg er utydelig i mine beskjeder, så frustrere det både meg selv og de andre. Jeg har lyst til å være mere bestemt og fremstå som en som er selvsikker.

En fjerde kvinnelig informant, som også opplevde en stor grad av overskudd, både fysisk og mentalt, gir uttrykk for noe av det samme, men kobler usikkerheten til det å kommunisere med gruppen:

I en del situasjoner ønsker jeg å være mer tydelig. Grunnen til at jeg blir for utydelig er at jeg kanskje ikke helt har bestemt meg for hva jeg selv synes om den aktuelle saken. I tillegg er jeg nok mer demokratisk enn autoritær. Kombinasjonen av disse to egenskapene kan ofte ende opp som utydelig kommunikasjon. Derfor må jeg være mer 
klartenkt i forhold til hva jeg selv mener og så må jeg i noen situasjoner være litt mer autoritær. Jeg har nok en tendens til å ønske at alle skal få lov til å mene noe om alt, og glømmer at det for mange er en lettelse at de slipper å involvere seg.

Noen av sitatene ovenfor leder over til temaet kommunikasjon og roller.

\section{Kommunikasjon og roller}

I dette avsnittet vises det hvordan informantene uttrykker sine opplevelser knyttet til kommunikasjon og roller, med hovedvekt på mellommenneskelig ferdigheter og selvkontroll. Dette er temaer som dukker opp både når de får i oppgave å reflektere over hva de har lært personlig, og i forbindelse med refleksjon rundt sine egenskaper som leder/veileder. En informant skriver følgende om roller:

Det må passe med ens egne forutsetninger. Men dette med å kunne ta forskjellige roller, være de forskjellige "puslespillbitene”, ser jeg på som en god egenskap. Dette for å kunne passe inn i forskjellige typer grupper; tilpasse seg, og skape en god atmosfære, uavhengig av gruppe ”type”.

Og den mannlige informanten fortsetter med å reflektere over seg selv som kommunikator, både som gruppemedlem og som veileder:

Jeg snakker mye, og jeg liker det. [...] Jeg opplever at jeg relativt ofte er den som åpner for kommunikasjonen, hvor jeg gjerne spør etter folks ønsker og meninger, for å komme frem til hva det er vi står overfor. [...] Min mening rundt dette, og spesielt knyttet til veilederrollen, er at det er positivt og hensiktsmessig å ta denne rollen en hel del, og få løftet frem kommunikasjon.

Sannsynligvis har denne typen refleksjoner som informanten gjør seg her potensiale til å utvikle vedkommende personlig, både i forhold til seg selv som en del av fremtidige grupper, og i forhold til seg selv som veileder for fremtidige grupper. I forlengelsen av temaet kommunikasjon og roller finnes også utsagn fra informanter som reflekterer over viktigheten av selvkontroll og det å kunne moderere seg i samspillet med øvrige gruppemedlemmer. Av sitatet nedenfor har den kvinnelige informanten vært igjennom en fase med selvrefleksjon også før turen, og evner her å ta opp tråden i etterkant:

Mit helhedsindtryk både på turen og efterfølgende er at vi havde en god stemning. Vi klarede at snakke pænt til hinanden med meget få undtagelser, $\mathrm{fx}$ i lettere pressede situationer hvor vind, træthed og kulde påvirkede os på skift. [...] Jeg havde før turen besluttet mig for at være god til at tælle til 10. Jeg ville arbejde med min tolerance og prøve at opføre mig som en vejleder i tillæg til et gruppemedlem.

En mannlig informant viser også at han har gått i seg selv, og reflektert over hvordan han til tider kommuniserer på en uheldig måte: 
Eg merkar på meg sjølv at i somme situasjonar blir eg kanskje litt utålmodig når folk somlar unødvendig i forhold til kva eg synest er nødvendig. Her kan det skje at eg er litt kjapp med å ”kjefte” litt for å få folk til å gjere det eg meiner er rett.

\section{Leder- og veilederrollen}

Her gjøres det rede for hvordan informantene opplever at de utvikler seg med hensyn til lederskap. Flere reflekterer over at trygghet i veilederrollen har sammenheng med god planlegging, det å ha en viss struktur, samt det å ha evnene til å se framover.

Når respondentene i denne undersøkelsen fikk spørsmålet: "Hva har du lært om dine egenskaper som leder/veileder under ferden?”, settes det i gang en rekke ulike refleksjoner. Flere av informantene har en relativt praktisk tilnærming. En kvinnelig informant understreker viktigheten av å være tydelig og nå frem med budskapet, når hun sier at hun: ”Må være mer tydelig i språket og det jeg vil få frem. Huske å samle gruppen, for så å informere så alle får med seg hva som skjer. Og tydelig på at det er jeg som er leder”. Denne informanten var dagsansvarlig under et døgn med svært krevende værforhold hvor det ble tatt noen omdiskuterte avgjørelser. I kjølvannet av dette reflekter vedkommende videre, og dypere rundt sin rolle som leder/veileder:

På turen merket jeg også at jeg i større grad burde tatt det lederansvaret jeg fikk. Stole på mine egne tanker og synspunkter, og formidle disse på en god måte til gruppen. Jeg er sikker, og det må jeg få frem. Uklar, utydelig og tafatt. Jeg skulle så gjerne ha gjort så mye mer, men jeg gjorde lite [...] noe som ikke passet like godt på en dårlig værdag. For eksempel leirplassen midt i vindhavet, som var en utrolig dårlig løsning, og som jeg ikke klarte å slutte å irritere meg over.

Viktigheten av en viss struktur, planlegging og framsynthet er også noe som flere informanter reflekterer over. En kvinnelig informant har erfart at det å tenke fremmover, det å ha en plan, og det å ha tenkt igjennom ulike scenarioer gir en følesle av trygghet:

Eg oppdaget også når eg var veileder at det var viktig å heile tida tenke framover, og ha ein plan for dagen og opplegget. På førehand hadde eg meir tenkt å ta ting litt etter kvart og sjå korleis det utarta seg. Det er noko eg vil prøve å endre til neste gang eg får ein slik rolle, då eg trur det kan gjere meg tryggare på meg sjølv og mine val viss eg har tenkt gjennom ulike scenario på førehand.

Av dette sitatet ser vi at informantene har ambisjoner om å ta med seg denne erfaringen, med tanke på endring, i forkant av fremtidige veilederoppdrag. Som en oppfølging på dette er det relevant å trekke frem en mannlig informant som har gjort seg mange av de samme tankene:

Det er i stort sett alle samanhenger godt å vere strukturert som vegledar. Under det å vere strukturert meiner eg at ting som evna til å sjå framover og god planlegging kjem 
inn under. Utad i gruppa har ein og mykje igjen for å vere strukturert. Ein blir oppfatta som om ein har ting på stell, er erfaren og som om ein har god kontroll.

\section{Mellommenneskelig relasjoner}

I det følgende belyses hvordan informantene uttrykker sin opplevelse av personlig utvikling i forbindelse med mellommenneskelige forhold knyttet til utøvelsen av lederskapet/ veilederrollen. Informantene reflekterer bl.a. over omsorgsoppgavene som lederskapet innebærer, som det å ha overblikk, lese situasjoner, gjøre vurderinger og treffe nødvendig tiltak. En mannlig informant skriver f.eks. følgende om seg selv i veilederrollen:

Jeg mener jeg er god til å oppmuntre de andre i gruppen. Samtidig har jeg en god fornemmelse av de andre i gruppen, og merker hvordan de har det. Jeg merker hvis noen er leie seg, trøtte eller sultne, og jeg er sånn sett god til å lese de andre i gruppen. Jeg prøver å være positiv og bidra til et godt miljø i gruppen.

Informanten fremhever det å fornemme den enkelte, det å oppmuntre, være positiv og gi omsorg. Denne typen refleksjoner knyttet til veilederrollen var en gjenganger blant flere av informantene:

Det er viktig å forsøke å holde et overblikk over de forskjellige tilstander blant gruppedeltagerne; og da gjerne gjennom kommunikasjon. f.eks. gå å småprate litt med de forskjellige, og få en følelse av hvordan de har det og hva som vil være bra for den enkelte. På samme måte kunne dette komme frem i pauser eller samlinger.

Temaer knyttet til overblikk for gruppen og for den enkelte fremheves som viktig også av denne mannlige informanten:

Vi er inne på overblikket. Å forsøke å få tak i de forskjellige gruppemedlemmenes ønsker, verdier, mål. Og tilstand, ikke minst. Dette krever fokus på akkurat dette [...]. A ta utgangspunkt i deltagerne, er for meg noe av det mest sentrale for gode opplevelser, og dermed må vi forsøke å sette oss inn i alle deltagerne, slik at vi ikke bare tilfredsstiller noen.

Overblikket, som er fremhevet hos flere, henger nøye sammen med det å ha omsorg for gruppen og den enkelte. En av informantene gir nærmest uttrykk for å være litt brydd over sin egen sensitivitet, men konkluderer med at denne siden ved sin person gjør ham til en bedre veileder:

Blandt annet viderereflekter jeg på omsorgsperspektivet hos en veileder, hvor jeg tror at jeg kanskje skiller meg noe ut; har en litt andreledes tilgang, enn mange andre. Jeg er en sensitiv person. [...] Og ut i fra dette, jobber jeg videre med hvordan denne sensitivitet kan brukes i veiledersammenheng, samtidig som jeg forsøker å bevisstgjøre og justere på noen av ulempene ved denne. 
Sitatene ovenfor viser refleksjoner rundt lederskap som går i retning av å understreke viktigheten av de mellommenneskelige forhold knyttet til utøvelsen av lederskapet/ veilederrollen. I forlengelsen av omsorgsperspektivet omtaler en av informantene viktigheten av at veilederen kan lese situasjoner og løpende foreta vurderinger, samt treffe nødvendig tiltak når situasjonen krever det:

\begin{abstract}
I denne sammenhæng mener jeg at have lært om mig selv på denne tur at jeg langt hen af vejen er god til at læse situationer og folk og dermed kan træde til og bidrage med det nødvendige når der er brug for det. Jeg har følt at jeg i hvert fald $90 \%$ af tiden på turen har haft overskud nok til løbende at kunne gøre disse vurderinger på en god og konstruktiv måde. Dette ser jeg som særdeles vigtig som kommende vejleder at kunne være i stand til at gøre disse vurderinger da de kan være alpha og omega for at en gruppe man har med på tur kommer til at fungere godt.
\end{abstract}

Tematikken demokratisk versus autoritær lederstil er det flere av informantene i denne studien som er opptatt av. En kvinnelig respondent uttrykker seg slik: ”På den positive sida opplever jeg å ha en stemme og ei framtoning som blir hørt og respektert. Dette tror jeg bunner i trygghet, erfaring og personlighet. På denne ferden opplevde jeg også å ha stort overskudd både ferdighetsmessig og fysisk”. Innenfor den samme tematikken er det relevant å ta med ett sitat fra en kvinnelig informant som ser seg selv gjennom å observere medstudenter:

Videre så merket jeg at jeg ikke likte å bli overstyrt. En som var veileder tok en avgjørelse over hodet på resten av gruppen. Det likte jeg dårlig. Men da jeg selv var veileder så gjorde jeg akkurat det samme uten å tenke over det. Så jeg vil bli flinkere til å vurdere hva slags avgjørelser som egner seg for å taes opp i plenum og ikke. Dette går på kommunikasjon. Jeg er ikke spesielt god på kommunikasjon.

I lys av resultatene presentert her er det legitimt å påstå at turer/ferder i norsk tradisjon trolig kan ha vel så stor innvirkning på personlig utvikling, karakterdannelse og utvikling av lederegenskaper som "youth expedtitions" i britisk og angloamerikansk tradisjon. Som sagt innledningsvis ligger dette imidlertid utenfor det som har vært anliggende her, men det er et problemområde det kan være interessant å se nærmere på i en annen studie.

\title{
Diskusjon og konklusjon
}

Opplever norske bachelorstudenter i friluftsliv at de larer/erfarer noe om seg selv under lange, krevende ferder i vinterfjellet? På grunnlag av datamaterialet i denne studien kan det konkluderes at omtrent halvparten av respondentene gir uttrykk for en opplevelse av at de har lært noe om seg selv. Disse lærdommene handler i stor grad om erfaringer knyttet til selvbilde/identitet som kan koples til personlige utvikling. Særlig reflekteres det over opplevelser knyttet til det å mestre og prestere, det å akseptere egne styrker og svakheter, samt det å utvikle 
troen på seg selv, også i lederrollen. I tillegg reflekteres det over opplevelser av læring knyttet til mellommenneskelig ferdigheter, selvkontroll og kommunikasjon.

Funnene i denne studien korrespondere godt med Mezirows transformative læringsteori der handling, her gjennom lange skiekspedisjoner, frembringer nye erfaringer hos respondentene. De nye erfaringene setter i gang kognitive prosesser hos respondentene som leder til oppdagelse av nye konstruksjoner, og som gjør de forvirrende elementene mer forståelig. Videre reflekterer respondentene over hvordan de kan/bør tilpasse seg og evt. endre atferd. Denne læringen kan da sies å være ledd i en personlig utvikling. Om respondentene faktisk endrer atferd er et spørsmål som ligger utenfor denne studien å besvare.

Analyserer vi hvordan respondentene beskriver "handlingen", altså skiekspedisjonen, og hvordan de har opplevd denne på kroppen, finner vi noe interessant. Mye tyder på at det er de som gir uttrykk for å at ferden (handlingen) har vært fysisk og psykisk anstrengende som i størst grad har gjort seg refleksjoner rundt sin egen person som er relevant for den enkeltes selvbilde/identitet og personlige utvikling. Dette stemmer bra overens med funn i en undersøkelse gjort av Scherl og Smithson (1986) som viser at situasjoner som påkrever stor anstrengelse, mentalt og/eller fysisk, fører til refleksjon og oppmerksomhet rundt sin egen person og selvbilde/identitet (Hattie, Marsh, Neill, \& Richards, 1997, s. 72). Deres undersøkelse, av effektene av et Outward Bound program, viste at $46 \%$ av gangene ordet anstrengelse (effort) ble brukt av deltakerne, var det også en referanse til sin egen person/selvbilde (self). I den forbindelse hevder de at: "The exertion of mental and physical effort is directing one's attention to oneself" (Hattie, Marsh, Neill, \& Richards, 1997, s. 47). Videre påpeker de at denne typen anstrengelser ser ut til å bidra til at deltakerne reflekterer over seg seg selv i lys av det å mestre og prestere: "[...] this is a very specific type of awareness about the self; that is, when people exert physical and mental effort in that context, they look at themselves mainly in terms of coping” (Hattie, Marsh, Neill, \& Richards, 1997, s. 47). Dette er en observasjon som man langt på vei finner støtte for i resultatene presentert ovenfor. Informanter som ikke har opplevd ferdene som spesielt anstrengende uttaler i langt mindre grad at de har lært noe om seg selv. Informanter som har opplevd ferdene som anstrengende illustrer det motsatte og underbygger funnene til Scherl og Smithson (1986).

Refleksjon rundt selvkontroll er et annet område som "handlingen” i denne studien ser ut til å "aktivere”. Dette korresponderer også med effekter som også forventes av "adventure programms" og "educational expeditions". Hattie m.fl. (1997) viser eksempelvis til en studie gjort av Scherl (1988) som peker på refleksjon rundt selvkontroll som en nærmest naturlig del av det å ferdes i utfordrende og uforutsigbare, naturlige omgivelser: "A wilderness environment is challenging and unpredictable, and thus any person who is interacting with that environment, to be effective, must actively modify his or her behavior. The 
only effective way to do this [...] is to develop and maintain self-control” (s. 67).

Flere av sitatene under avsnittet "kommunikasjon og roller" i resultat delen ovenfor tyder på at "ferden" i norsk tradisjon, som handling, kan stimulere til refleksjon både rundt kommunikasjon, roller og mellommenneskelige forhold. Nettopp temaer knyttet til utvikling av mellommenneskelig ferdigheter har tradisjonelt vært et viktig mål i forbindelse med "educational expeditions" i britisk og angloamerikansk tradisjon. Studien til Hattie m.fl. (1997) slår fast at "adventure programms" har effekt på mellommenneskelig forhold: "It certainly appears that adventure programs affect the social skills of participants in desirable ways. [...] This is particularly noted with social competence, coorperation, and interpersonal communication” (s. 69).

Opplever de samme studentene at de lerer/erfarer noe om sine egenskaper som leder/veileder under disse ferdene? Stort sett de samme studentene som opplever at de har lært noe om seg selv opplever også at de har lært noe om sine egenskaper som leder/veileder. Flere reflekterer over at egen trygghet i veilederrollen har sammenheng med god planlegging, det å ha en viss struktur, samt det å ha evnene til å se framover. Dette samsvarer relativt godt med "adventure programs" og "educational expeditions" påståtte effekter på lederskap. Eksempelvis refererer Hattie m.fl. (1997) til en studie gjort av Stoltz (1992) som viser at organisasjonen Outward Bound gjennomgående hevder at deres kurs forbedrer "teamwork skills" og "leadership skills" blant deres deltakere. Og på grunnlag av sin meta-studie kunne Hattie m.fl. konkluderer med at: "[...] most adventure programs impact leadership competencies” (s. 67).

Erfaringer som informantene i denne studien har gjort seg ser også ut til å ha ført til økt forståelse for sammenhengen mellom problemløsning, beslutningstaking og erfaringsbaserte vurderinger, som fremheves som en viktig del av lederskapsutviklingen innenfor "adventure programming", i boken Effective leadership in Adventure programming (Priest \& Gass, 1997, s. 271). Sitatene under avsnittet "Leder- og veilederrollen" ovenfor tyder på at informantene i denne studien har gjort seg erfaringer knyttet til det å samle informasjon og veie ulike muligheter opp mot hverandre, for så å løse en situasjon gjennom beslutningstaking, som ansees som en viktig del av lederskapsutviklingen i "adventure programming” (Priest \& Gass, 1997, s. 281).

Når det er sagt er det refleksjoner rundt mellommenneskelig forhold knyttet til utøvelsen av lederskapet/veilederrollen som dominerer. Særlig reflekterer respondentene over omsorgsoppgavene som lederskapet innebærer. Opplevelser av læring knyttet til det å ha overblikk, lese situasjoner, gjøre vurderinger og treffe nødvendig tiltak, er spesielt gjenstand for refleksjon. Og i forlengelsen av dette reflekteres det over viktigheten av å ha fornemme den enkelte, det å oppmuntre, være positiv og gi omsorg. Her kjenner vi igjen flere temaer som står sentralt i teorien knyttet til effekter av "adventure programming" og "educational expeditions". 
For det første fremhever Priest og Gass (1997, s. 70) at en leder bør være i stand til å identifisere faktorer som har effekt på gruppedynamikken i en gruppe, samt gjøre justeringer som bidrar til gruppens utvikling (1997, s. 70). For det andre peker de på følgende egenskaper hos en "Effective Outdoor Leader", som "adventure programming” kan bidra til å utvikle: "Be capable of observing behaviors, reassessing needs, setting objectives, and preparing activities to meet the objectives" (s. 185). Og for det tredje fremhever de at en "Outdoor Leader" må være: "[...] capable of establishing support, planning for action, and following up" (s. 185). Til slutt hevder de at "adventure programming" skal bidra til at kandidatene kan utvikle en åpen og relativt demokratisk lederstil: "Be open to rewiewing and discussing their own judgements with others, thereby improving their future judgement” (s. 261). Samlet sett ser vi her en rekke sammenfallende elementer mellom forventede effekter av "adventure programming” og funnene i denne studien av "educational expeditions" i en norsk tradisjon.

\section{Etterord}

Avslutningsvis kan det hevdes at vinterferder i norsk friluftslivspedagogisk tradisjon har et pedagogisk potensiale mht. personlig utvikling og utvikling av lederegenskaper, som neppe står tilbake for brittisk og angloamerikansk tradisjon. Kanskje vil funnene presentert her bidra til å øke bevisstheten rundt det pedagogiske potensialet som ligger i menneskers møter med andre mennesker i natur, blant friluftslivets pedagoger i Norge?

\section{Referanser}

Asfeldt, M., Hvenegaard, G., \& Urberg, I. (2010). Expeditions and Liberal Arts University Education. I S. Beams, Understanding Educational Expeditions (s. 67-78).

Rotterdam/Boston/Taipei: Sense Publishers.

Asfeldt, M., Potter, T., \& Henderson, B. (2013). Outdoor Adventure Education in Canada: Characteristics and Influencees. Akzent e \& 1,3 \& 4.

Beams, S. (2004). Critical elements of an expedition experience. Journal of Adventure Education and Outdoor Learning 4, s. 145-158.

D’Amato, L. G., \& Krasny, M. E. (2011). Outdoor Adventure Education: Applying Transformative Learning Theory to Understanding Instrumental Learning and Personal Growth in Environmental Education. The Journal of Environmental Education, 42(4), s. 236-254.

Dewey, J. (1938). Experience and education. New York: Simon \& Schuster.

Dimock, H. S., \& Henday, C. E. (1929). Camping and Character: A Camp Experiment in Character Education. New York: NY: Association Press.

Faarlund, N. (1974). Friluftsliv, hva, hvorfor, hvordan. Hemsedal: HNA trykk. 
Hattie, J. A., Marsh, H. W., Neill, J. T., \& Richards, G. E. (1997). Adventure education and Outward Bound: Out-of-class experiences that make a lasting difference. Review of Educational Research, 67(1), s. 43-87.

Holme, I. M., \& Solvang, B. (1993). Metodevalg og metodebruk. Otta: Tano as.

Loynes, C. I. (2010). The British youth expedition: Cultural and historical perspectives. I S. Beams, Understanding Educational Expedtions (s. 1-16). Rotterdam/Boston/Taipei: Sense Publishers.

Mohn, E. M. (1873). Eventyr tilfjelds. I DNT, Turistforeningens årbok (s. 7-19). Kristiania: Den Norske Turistforening.

National Outdoor Leadership School. (2012). Nols. Hentet fra http://www.nols.edu/about/

Outward Bound. (2012). Outward Bound. Hentet fra http://www.outwardbound.net/about/history/kurt-hahn.html

Priest, S., \& Gass, M. A. (1997). Effective Leadership in Adventure Programming. Champaign: Human Kinetics.

Raffan, J. (2002). Deep Waters. Courage, Character, and the Lake Timiskaming Canoeing Tragedy. Toronto: Harper Flamingo.

Scherl, L. A. (1988). Constructions of a wilderness experience: Using the repertory grid technique in a natural setting. Australian Psychologist, 23, s. 225-242.

Scherl, L. A., \& Smithson, M. (1986). A new dimension to content analysis: Expolring relationships among thematic categories. Paper presented at the 15th Annual meeting of the Australian Socila Psychologists. Magnet Island, Queensland, Australia.

Stoltz, P. G. (1992). An examination of leadership development in the great outdoors. Human Resource Development Quarterly, 3, s. 357-372.

Stonehouse, P. (2010). Virtue Ethics and Expeditions. I S. Beams, Understanding Educational Expeditions. Rotterdam/Boston/Taipei: Sense Publishers.

The Woodcraft folk. (2012). Woodcraft folk. Hentet fra http://woodcraft.org.uk/history Tordsson, B. (2010). Friluftsliv, kultur og samfunn. Kristiansand: Høgskoleforlaget.

Tordsson, B. (2014). Perspektiv på friluftslivets pæedagogik. København: Books on Demand. Veiden, P. (2000). Innledning. I P. L. Berger, \& T. Luckmann, Den samfunnsskapte virkelighet (s. 7-19). Oslo: Fagbokforlaget.

Winsnes, A. H. (1942). Nansens røst. Oslo: Jacob Dybwads forlag. 